\title{
Pleural disease during treatment with bromocriptine in patients previously exposed to asbestos
}

\author{
G. Hillerdal*, J. Lee**, A. Blomkvist+, A. Rask-Andersen++, M. Uddenfeldt ${ }^{+}$, \\ H. Koyi , E. Rasmussen $\neq$
}

Pleural disease during treatment with bromocriptine in patients previously exposed to asbestos. G. Hillerdal, J. Lee, A. Blomkvist, A. Rask-Andersen, M. Uddenfeldt, H. Koyi, E. Rasmussen. CERS Journals Ltd 1997.

ABSTRACT: Bromocriptine, which is used in the treatment of Parkinson's disease, can cause adverse pleuropulmonary reactions. Exposure to asbestos can result in similar lesions.

Fifteen patients with former exposure to asbestos, who developed pleural fibrosis after treatment with bromocriptine, were observed independently in Sweden (11 patients) and Australia (four patients).

The patients complained of malaise, often associated with weight loss, dyspnoea, and a disturbing cough. Laboratory values included increased erythrocyte sedimentation rate and a low haemoglobin level. Lung function tests showed a restrictive lung function defect. Chest radiographs showed bilateral pleural fibrosis, with small amounts of fluid in some cases. Soon after bromocriptine was withdrawn, the patients improved clinically, and the laboratory values returned to normal. However, in most cases, pleural fibrosis and a restrictive lung function defect persisted to some extent.

In conclusion, in patients who develop pleuropulmonary fibrosis whilst being treated with bromocriptine, former exposure to asbestos should be investigated. Conversely, when pleural changes develop in a patient on bromocriptine and with prior exposure to asbestos, the possible causative role of the drug should be discussed. Special follow-up may be indicated when bromocriptine is planned in a patient with previous asbestos exposure, and if symptoms or signs of pleural fibrosis develop, bromocriptine withdrawal should be considered.

Eur Respir J 1997; 10: 2711-2715.
Depts of *Lung Medicine and $\stackrel{+}{*}$ Thoracic Radiology, Karolinska Hospital, Stockholm,

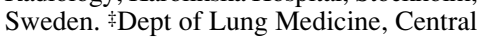
Hospital, Gävle, Sweden. ++Dept of Occupational Medicine, Uppsala University Hospital, Uppsala, Sweden. +Dept of Occupational Medicine, Örebro University Hospital, Örebro, Sweden. **RPAH Medical Centre, Newtown, NSW, Australia.

Correspondence: G. Hillerdal

Dept of Lung Medicine

Karolinska Hospital

S-17176 Stockholm

Sweden

Keywords: Adverse drug reactions

asbestos

bromocriptine

lung fibrosis

pleural fibrosis

pleurisy

Received: March 211997

Accepted after revision July 101997
Bromocriptine, a semisynthetetic ergot alkaloid derivative, acts as a dopamine agonist [1]. The drug has been successfully used for the treatment of Parkinson's disease and prolactinoma. In 1981, RinNe [2] reported that, out of 123 patients on long-term therapy with this drug, seven had developed pleuropulmonary reactions. Since then, to our knowledge, 30 cases of bromocriptine-induced adverse reactions in the lung and/or pleura have been reported in the literature [3-18]. Interestingly, ergot alkaloids other than bromocriptine can cause similar lesions in the chest [19].

Occupational exposure to asbestos is another wellknown cause of pleural and lung disease. The pleural lesions are of various types [20]. One form, the diffuse pleural fibrosis, is less common but more severe, in terms of restrictive lung disease, than simple pleural plaques. This pattern is clinically and radiologically similar to the adverse reactions from bromocriptine.

When a patient formerly exposed to asbestos happens to develop Parkinson's disease, is treated with bromocriptine, and develops diffuse pleural thickening, an interesting differential diagnosis is raised, After having seen 15 patients with this particular association, we would

For editorial comment see page 2695 like to report on these cases and suggest that there may be a synergistic effect between these two factors. In other words, the risk of adverse respiratory effects from bromocriptine may be enhanced in persons who have previously been exposed to asbestos [21].

\section{Materials and methods}

All patients were reviewed if they had been referred to or evaluated by one of the authors during the period 1986-1997 because of restrictive lung function defect caused by pleural and/or pleural-parenchymal lesions, and had been exposed to asbestos in the past and were being treated with bromocriptine. Eleven patients were seen in Sweden and four in the Sydney region of Australia. No attempts were made to recruit other patients in a systematic fashion, nor was an epidemiological study performed among patients treated with bromocriptine or in cohorts of subjects formerly exposed to asbestos. Clinical and laboratory data, such as the erythrocyte sedimentation rate (ESR) and haemoglobin concentration, were tabulated.

A chest radiograph was available for review in each patient, and a computed tomography (CT) scan was 
available in 10 cases. Lung function tests were performed in 10 cases, but in five patients with severe symptoms from their Parkinson's disease, even simple tests could not be performed. Bronchoalveolar lavage (BAL) was performed in two patients, as described elsewhere [22].

Once the diagnosis was established, bromocriptine was withdrawn, and the patient was followed-up.

\section{Results}

\section{Symptoms and signs}

The patients usually presented after a period of up to 6 months with malaise; their other main complaints were dyspnoea on exertion and a troublesome cough. Weight loss was a common finding, and a number of patients had been extensively investigated for suspicion of malignancy by general practitioners or internists.

\section{Laboratory values}

An increased ESR was found in 10 of the 11 patients for whom data were available (table 1), and a low haemoglobin level was seen in all cases. There were also other nonspecific laboratory findings compatible with ongoing inflammation, such as an increased platelet count, or immunoglobulins $\mathrm{A}$ and $\mathrm{G}$ (IgA and $\mathrm{IgG})$, and a high level of C-reactive protein (CRP).

\section{Bronchoalveolar lavage}

A BAL was performed in only two cases, and yielded normal results.

\section{Radiology}

Chest radiographs showed diffuse bilateral pleural thickening in all patients (figs. 1 and 2). In six patients, pleural fluid was present at some stage of the disease, and, in four cases, thoracocentesis yielded a small-tomoderate amount of fluid $(30-300 \mathrm{~mL})$ containing inflammatory cells, with a predominance of lymphocytes (actual percentages unavailable). On the CT scan, there was pleural thickening/fibrosis in all cases, but, usually, no evidence of parenchymal fibrosis was seen. Rounded atelectasis (fig. 1a) was seen in five of the 15 patients.

\section{Lung function tests}

Dynamic spirometry was available in 12 patients, and showed a low forced vital capacity (FVC) (mean \pm SEM) $62 \pm 3 \%$ predicted (range $50-81 \%$ pred). Static spirometry was available in eight cases and showed a restrictive pattern: total lung capacity (TLC) averaged $66 \pm 2 \%$ pred (range $58-73 \%$ pred) and residual volume (RV) averaged $80 \pm 6 \%$ pred (range $61-109 \%$ pred).

\section{Histology}

In five patients, pleural biopsy were performed (one by thoracotomy and four via a needle biopsy). All biopsies showed extensive nonspecific fibrosis.

\section{Follow-up}

Follow-up ranged 1-8 yrs, except in the two most recent cases, which were seen in 1997. After withdrawal of the drug, clinical symptoms, such as cough and malaise, disappeared after a few days, and the laboratory values (including ESR and haemoglobin) level returned to normal after periods ranging from a few weeks to 2 months. Lung function improved only slightly, or remained unchanged, and a restrictive lung function defect often remained due to pleural fibrosis. Case No. 14 is a typical example, as described below. His FVC was 5.0 L (96\% pred) before treatment with bromocriptine, dropped to $3.0 \mathrm{~L}(62 \%$ pred) under treatment with the drug, and returned to $3.5 \mathrm{~L}$ ( $71 \%$ pred) after the drug was stopped.

Table 1. - Characteristics of the patients studied

\begin{tabular}{|c|c|c|c|c|c|c|c|c|}
\hline \multirow{2}{*}{$\begin{array}{l}\mathrm{Pt} \\
\text { No. }\end{array}$} & \multirow{2}{*}{$\begin{array}{c}\text { Age } \\
\text { when } \\
\text { seen } \\
\text { yrs }\end{array}$} & \multirow{2}{*}{$\begin{array}{c}\text { Age on } \\
\text { asbestos } \\
\text { exposure } \\
\text { yrs }\end{array}$} & \multirow[t]{2}{*}{ Occupation } & \multicolumn{2}{|c|}{ Bromocriptine } & \multirow{2}{*}{$\begin{array}{l}\text { ESR } \\
\text { when } \\
\text { seen }\end{array}$} & \multirow{2}{*}{$\begin{array}{c}\text { ESR } \\
\text { after drug } \\
\text { withdrawn }\end{array}$} & \multirow[t]{2}{*}{ Comments } \\
\hline & & & & $\mathrm{mg} \cdot$ day $^{-1}$ & yrs & & & \\
\hline 1 & 66 & $20-60$ & Building worker & 20 & 5 & 60 & 15 & Plaques \\
\hline 2 & 66 & $19-59$ & Building worker & 20 & 4 & 45 & 15 & Plaques \\
\hline 3 & 66 & $22-58$ & Building painter & 5 & 10 & 65 & 14 & Plaques \\
\hline 4 & 62 & $20-57$ & Building worker & 20 & 5 & 80 & 14 & Plaques \\
\hline 5 & 60 & $18-33$ & Chemical factory & 20 & 4 & 117 & 5 & Also asthma \\
\hline 6 & 77 & $40-47$ & Chemical factory & 7.5 & 8 & 80 & - & Plaques \\
\hline 7 & 79 & $20-65$ & Retail* & 17.5 & 5 & 95 & - & Plaques \\
\hline 8 & 70 & $45-46$ & Farmer" & 30 & 5 & 100 & - & $\begin{array}{l}\text { Badly restrictive, } \\
\text { now on oxygen }\end{array}$ \\
\hline 9 & 64 & $20-57$ & Building painter & $15-20$ & 7 & 9 & 7 & Plaques \\
\hline 10 & 75 & $20-50$ & Chemical engineer & 30 & 1.5 & - & - & Plaques \\
\hline 11 & 68 & - & Builder & 20 & 1.5 & - & - & Plaques \\
\hline 14 & 54 & $20-34$ & Electrician & 10 & 8 & 90 & 13 & \\
\hline 15 & 60 & $18-36$ & Building worker & 30 & 10 & 90 & - & \\
\hline
\end{tabular}

Pt: patient; ESR: erythrocyte sedimentation rate; Plaques: plaques known before pleural fibrosis. *: worked in a hardware store where asbestos was cut, mixed and sold; \#: frequently constructed barns etc. using asbestos; $¥$ : worked in an asbestos mine. Patients 12 and 13 not included since exact exposure data are missing. 
a)

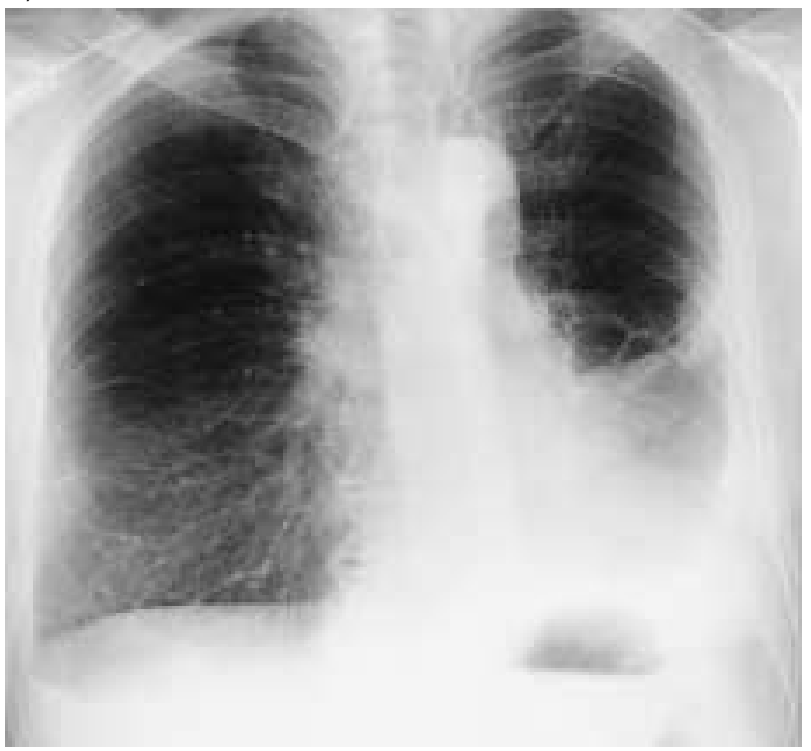

b)

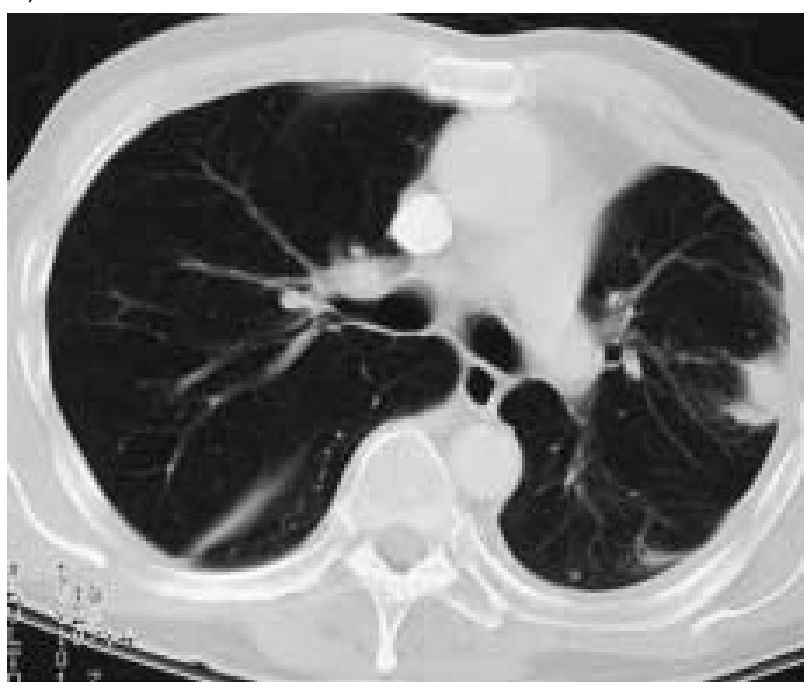

Fig. 1. - a) Chest radiograph of patient No. 9, frontal view. Bilateral pleural thickening is visible, more advanced on the left side where there is a small amount of pleural fluid and a rounded atelectasis. b) Computed tomography scan of patient No. 9, showing small round left-sided atelectasis.

\section{Illustrative case reports}

Case No. 9

This man was referred to the Department of Lung Medicine, Karolinska Hospital, Stockholm, Sweden at 64 yrs of age because of bilateral lung lesions. He was a nonsmoker and had been working in the building industry with direct and indirect exposure to asbestos for 37 yrs. In 1985, a chest radiograph showed bilateral pleural plaques. He had been suffering from Parkinson's disease for $8 \mathrm{yrs}$, and had been treated with bromocriptine, $20 \mathrm{mg} \cdot \mathrm{day}^{-1}$, for the past $5 \mathrm{yrs}$. Approximately 6 months before referral, he noticed a dry cough and increasing tiredness. He had lost a few kilograms in weight, but his main problem was increasing dyspnoea. a)

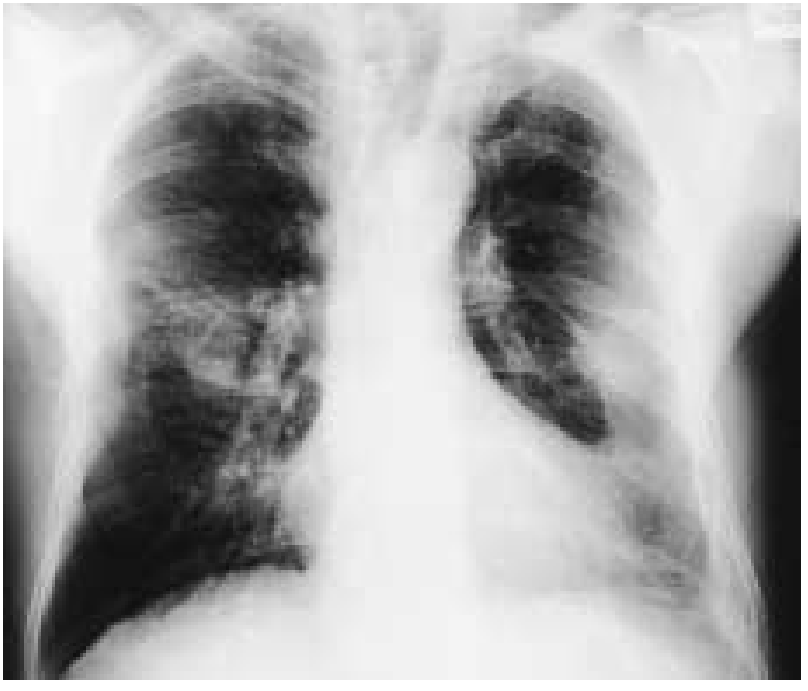

b)

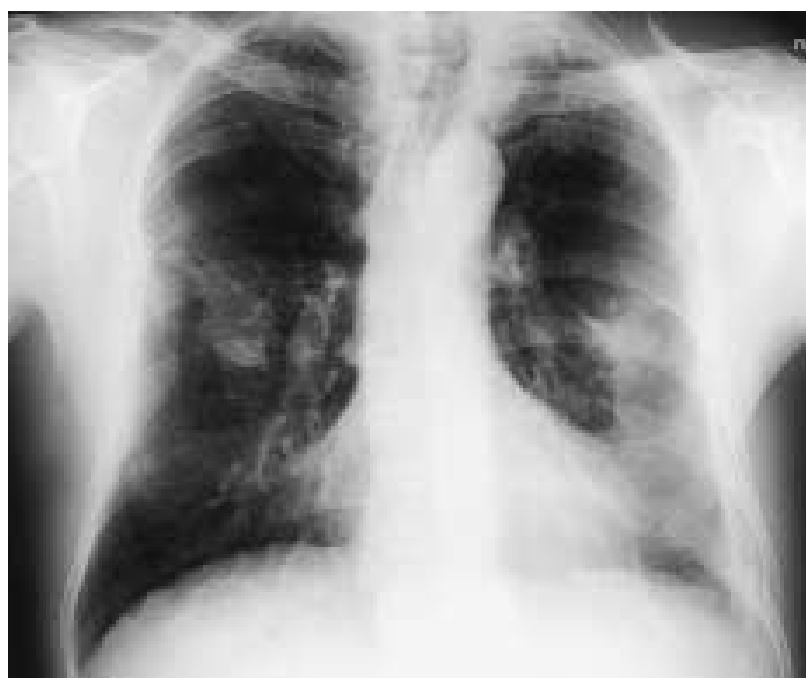

Fig. 2. - Chest radiographs of patient No. 15, frontal view. a) At presentation: extensive plaques are seen on the right side, and diffuse pleural thickening on the left side, together with bilateral rounded atelectasis. b) Two months after withdrawal of bromocriptine: there is a small improvement, but extensive pleural fibrosis remains.

Laboratory tests showed an ESR of $80 \mathrm{~mm} \cdot \mathrm{h}^{-1}$, and a haemoglobin level of $105 \mathrm{~g} \cdot \mathrm{L}^{-1}$. The chest radiograph showed bilateral pleural lesions, with the left side predominantly affected, and some fluid was present. A thoracocentesis yielded $30 \mathrm{~mL}$ of yellowish fluid; and cytology showed a predominance of lymphocytes. A CT scan confirmed that the lesions were mainly pleural, and there was a small amount of fluid (fig. 1). Spirometry showed TLC $68 \%$ pred, and vital capacity (VC) $50 \%$ pred. Bronchoscopy was normal. A needle biopsy showed a fibrotic and thickened pleura but no malignant cells.

Bromocriptine was withdrawn and, 2 months later, the patient no longer suffered from cough, had regained his original weight and felt much better, but dyspnoea was little improved. Laboratory values were back to normal. The chest radiograph no longer showed fluid, but pleural thickening remained nearly unchanged. 


\section{Case No. 14}

The patient was referred at 54 yrs of age to the Department of Occupational Medicine in Uppsala, Sweden, for suspicion of asbestosis. He had been working as an electrician in a mine since his teenage years, and had used asbestos for insulation purposes from the start and until he was 36 yrs old. He had been followed with spirometry and chest radiographs sporadically. In 1991, when 49 yrs of age, he had a normal chest radiograph, his VC was $5.0 \mathrm{~L}$ (96\% pred), and he weighed $85 \mathrm{~kg}$.

At $46 \mathrm{yrs}$ of age, the first symptoms of Parkinson's disease were recorded. One year later, bromocriptine was prescribed, at a dosage of $2.5 \mathrm{mg}$ t.i.d., and the dose was gradually increased to $15 \mathrm{mg} \cdot \mathrm{day}^{-1}$. The patient was in good health and back to full-time work, with a good control of his Parkinson's disease. However, in the summer of 1996, at 53 yrs of age, he felt tired and had to restrict his normal activities. In August 1996, his FVC had fallen to $3.0 \mathrm{~L}$ (62\% pred). The ESR was $90 \mathrm{~mm} \cdot \mathrm{h}^{-1}$, and the haemoglobin level was $127 \mathrm{~g} \cdot \mathrm{L}^{-1}$. In December 1996, his haemoglobin level was $118 \mathrm{~g} \cdot \mathrm{L}^{-1}$, thrombocytosis was present and serum albumin was $29 \mathrm{~g} \cdot \mathrm{L}^{-1}$. The patient's weight was down to $70 \mathrm{~kg}$.

Bromocriptine was withdrawn, and, within 1 week, the patient felt better. Two months later, the ESR was $13 \mathrm{~mm} \cdot \mathrm{h}^{-1}$, the haemoglobin value $143 \mathrm{~g} \cdot \mathrm{L}^{-1}$, and VC was modestly increased to $3.5 \mathrm{~L}$ (71\% pred). The patient had regained some weight and, though still dyspnoeic on exertion, he had resumed his normal activities.

\section{Case No. 15}

This $60 \mathrm{yr}$ old man was a former building worker and had worked with asbestos for almost 20 yrs. He had never smoked. Parkinson's disease was diagnosed at the age of $42 \mathrm{yrs}$ and, due to gradual worsening of his symptoms, bromocriptine was prescribed at 50 yrs of age, with a final dosage of $30 \mathrm{mg} \cdot \mathrm{day}^{-1}$. The patient was referred to the Lung Department in Gävle (Sweden) for evaluation of bilateral lesions on the chest radiograph. During the last 3-4 months, he had felt tired and increasingly dyspnoeic during exercise, and also complained of a dry irritating cough. The ESR was $90 \mathrm{~mm} \cdot \mathrm{h}^{-1}$, haemoglobin $119 \mathrm{~g} \cdot \mathrm{L}^{-1}$, and CRP $58 \mathrm{mg} \cdot \mathrm{L}^{-1}$. A chest radiograph showed extensive bilateral pleural fibrosis with some fluid (fig. 2a). In order to rule out pleural mesothelioma, pleural needle biopsies were performed on three different occasions. All showed extensive fibrosis without malignancy.

Bromocriptine was withdrawn, and, 2 days later, the cough had disappeared. Two months later, there was a slight decrease in pleural lesions (fig. 2b), but pleural fibrosis remained. The laboratory values were back to normal.

\section{Discussion}

The first report on adverse respiratory effects due to bromocriptine was that by RinNe [2] in 1981, who reported that, out of 123 patients treated with the drug, seven developed pleuroparenchymal lesions. In fact, adverse fibrogenic effects from the drug seem more unusual in clinical practice than once suggested, and it has even been claimed that there is no significant overrepresentation of pleural lesions in patients treated with bromocriptine as compared to controls [23]. In addition to the original article by RINNE [2], 16 further reports comprising 30 patients overall have so far been published (table 2). The pleuropulmonary reaction to ergot drugs is usually a restrictive lung function defect, presumably due to extensive pleural fibrosis [19]. Increased ESR and a low haemoglobin level are also present, together with general malaise and loss of weight [19]. Pleural effusion with various amounts of fluid may also occur $[3,5,7,10,11,15,16,19]$.

The pleural lesions caused by asbestos are more common than those due to bromocriptine. For instance, in Nordic countries, the incidence of pleural plaques in males aged $\geq 40$ yrs ranges 2-7\% [24-27]. Pleural plaques do not usually cause a significant restrictive defect, or only a mild one. A less common asbestos-related manifestation is a diffuse pleural fibrosis, which can cause severe restrictive disease [20]. In the latter form of asbestos-induced pleural involvement, signs of inflammation, such as an increased ESR, have been described in serum, but generalized malaise is usually lacking [28]. As part of this pattern, acute or chronic pleurisies with various amounts of fluid, may also develop in asbestos workers.

How then, to differentiate between asbestos-related and bromocriptine-induced pleural disease in a given patient? The best way is probably to withdraw the drug in all suspected cases. If the general condition of the

Table 2. - Case reports of bromocriptine lung and pleural reactions from the literature

\begin{tabular}{|c|c|c|c|c|c|}
\hline [Ref.] & Sex & $\begin{array}{c}\text { Pts } \\
n\end{array}$ & $\begin{array}{l}\text { Age } \\
\text { yrs }\end{array}$ & $\begin{array}{l}\text { Bromocriptine } \\
\mathrm{mg} \cdot \text { day }^{-1}\end{array}$ & $\begin{array}{l}\text { Asbestos } \\
\text { exposure }\end{array}$ \\
\hline$[2]$ & M & 1 & 61 & $80-100$ & ND \\
\hline [3] & M & 1 & 44 & 50 & ND \\
\hline [4] & M & 1 & 56 & 62 & Unknown (1) \\
\hline [5] & M & 1 & 46 & 60 & $\begin{array}{c}\text { Asbestos } \\
\text { exposure } 25 \mathrm{yrs}\end{array}$ \\
\hline [6] & M & 4 & $61-66$ & 50 & $\begin{array}{c}3 \text { unknown (2) } \\
1 \text { asbestos } \\
\text { exposure }(3)\end{array}$ \\
\hline [7] & M & 1 & 55 & 20 & $\begin{array}{c}\text { Asbestos } \\
\text { exposure (4) }\end{array}$ \\
\hline$[8]$ & $\mathrm{M}$ & 1 & 64 & $30-40$ & ND \\
\hline [9] & M & 8 & $57-68$ & $6-50$ & ND \\
\hline [10] & M & 4 & $60-73$ & $15-40$ & ND \\
\hline [11] & M & 1 & 72 & 30 & ND \\
\hline [12] & M & 2 & 58,79 & 15,30 & ND \\
\hline [13] & M & 1 & 63 & 30 & ND \\
\hline [14] & $\mathrm{F}$ & 1 & 68 & 20 & ND \\
\hline [15] & M & 1 & 64 & 35 & $\begin{array}{c}\text { Asbestos } \\
\text { exposure (5) }\end{array}$ \\
\hline [16] & M & 1 & 42 & 10 & $\begin{array}{c}\text { Asbestos } \\
\text { exposure (6) }\end{array}$ \\
\hline [17] & M & 1 & 66 & $10-15$ & $\begin{array}{l}\text { ND, denied } \\
\text { asbestos } \\
\text { exposure }\end{array}$ \\
\hline
\end{tabular}

ND: not determined (no occupational history given); Pts: patients; M: male; F: female. The following occupational histories were given: (1) electrical engineer, no mention of asbestos; (2) electrical industry, no mention of asbestos; (3) automechanic; (4) machine operator; (5) goldsmith; (6) occupation not given. 
patients improves, the cough and general malaise disappear and the laboratory values normalize, then the case can probably be considered to be drug-related. As a consequence, further use of bromocriptine should be avoided. There are currently no data to indicate whether cross-sensitivity exists between bromocriptine and other ergot akaloids [19, 21]. Furthermore, we believe that caution should be exercised when prescribing bromocriptine to a patient known to have previous exposure to asbestos, because the risk of developing pleural lesions may be enhanced. Moreover, patients on bromocriptine, especially those with prior asbestos exposure, should be followed-up at regular intervals as regards the development of respiratory symptoms and/or signs of pleural fibrosis. If such signs develop, bromocriptine should be withdrawn, and other anti-Parkinson's disease drugs should be considered.

Our study does not provide epidemiological proof that asbestos potentiates the adverse effects of bromocriptine or other ergot alkaloids. An occupational history was given in only a few of the previous reports on ergot-induced respiratory dysfunction (table 2 ). Of the 30 previously reported cases, no occupational history was reported in 21 , and, of the remaining nine, five had been exposed to asbestos, while one was unexposed, and for three, the exposure was not clearly stated. Since the main exposure to asbestos occurred in industrialized countries in the 1960s and 1970s, an increasing number of previously exposed workers now reach the age at which Parkinson's disease may be seen. If an association exists between former exposure to asbestos and the risk of developing pleural disease upon exposure to bromocriptine, as suggested by our work, then an increasing incidence of such adverse effects may be expected to develop in the future.

\section{References}

1. Qinn N. Drug treatment of Parkinson's disease. BMJ 1995; 310: 266-270.

2. Rinne UK. Pleuropulmonary changes during long-term bromocriptine treatment for Parkinson's disease. Lancet 1981; i: 44.

3. Le Witt PA, Calne DB. Recent advances in the treatment of Parkinson's disease: the role of bromocriptine. J Neurol Transmission 1981; 51: 175-184.

4. Bottcher J, Grön U. Pleuropulmonale forandringer ved bromokriptinbehandling af parkinsonisme. Ugeskr Laeger 1981; 143: 2648-2649.

5. Vergeret J, Barat M, Taytard A, et al. Fibrose pleuropulmonaire et bromocriptine. Semin Hop Paris 1984; 60: 741-744.

6. Douvier JJ, Vergeret J, Taytard A, et al. La bromocriptine dans la maladie de Parkinson: toxicité pleuro-pulmonaire. Ann Med Interne (Paris) 1985; 136: 416-418.

7. Tornling G, Unge G, Axelsson G, et al. Pleuropulmonary reactions in patients on bromocriptine treatment. Eur $J$ Respir Dis 1986; 68: 35-38.

8. Wiggins J, Skinner C. Bromocriptine-induced pleural fibrosis. Thorax 1986; 41: 328-330.
9. Ward CD, Thompson J, Humby MD. Pleuropulmonary and retroperitoneal fibrosis associated with bromocriptine treatment. J Neurol Neurosurg Psychiatry 1987; 50: 1706-1707.

10. McElwaney G, Wilcox PG, Churg A, Fleetham JA. Pleuropulmonary disease during bromocriptine treatment of Parkinson's disease. Arch Intern Med 1988; 148: 2231-2236.

11. Kinnunen E, Viljanen A. Pleuropulmonary involvement during bromocriptine treatment. Chest 1988; 94: 1034-1036.

12. Diot E, Diot P, Le Rolland A, et al. Epanchements pleuraux induits par la bromocriptine. Rev Mal Respir 1990; 7: $1775-1777$.

13. Todman DH, Oliver WA, Edwards RL. Pleuropulmonary fibrosis due to bromocriptine treatment for Parkinson's disease. Clin Exp Neurol 1990; 27: 79-82.

14. Hely MA, Morris JGL, Lawrence S, et al. Retroperitoneal fibrosis, skin and pleuropulmonary changes associated with bromocriptine therapy. Aust NZ J Med 1991; 21: 82-83.

15. Bhatt MH, Keenan SP, Fleetham JA, Calne DB. Pleuropulmonary disease associated with dopamine agonist therapy. Ann Neurol 1991; 30: 613-616.

16. Schmid PA, Suter T, Speich R, et al. Bromocriptininduzierte Pleuropneumopathie. Dtsch Med Wochenschr 1994; 119: 1543-1546.

17. Vinge E, Odin P, Hansson L, et al. Pravidel kan ge lungförändringar. Läkartidningen 1994; 44: 4116-4118.

18. Klaasen REJL, Troost RJJ, Verhoeven GT, et al. Suggestive evidence for bromocriptine-induced pleurisy. Neth J Med 1996; 48: 232-236.

19. Pfitzenmeyer P, Foucher P, Dennewald G, et al. Pleuropulmonary changes induced by ergoline drugs. Eur Respir J 1996; 9: 1013-1019.

20. Hillerdal G. Asbestos-related pleural disease. Semin Respir Med 1987; 9: 65-74.

21. Blomqvist A, Palmér M. Asbestos, ergot alkaloids and pleuritis. Int J Occup Med Toxicol 1995; 4: 277-283.

22. Crystal RG, Reynolds HY, Kalica AR. Bronchoalveolar lavage. Chest 1986; 90: 122-131.

23. Weil C. The safety of bromocriptine in long-term use: a review of the literature. Curr Med Res Opin 1986; 10 : 25-51.

24. Hilt B, Lien JT, Lund-Larsen PG, Lund K, Langård S. Asbestos-related findings in chest radiographs of the male population of the county of Telemark, Norway: a cross-sectional study. Scand J Work Environ Health 1986; 12: 567-573.

25. Hillerdal G. Pleural plaques in the general population. Ann NY Acad Sci 1991; 643: 430-437.

26. Zitting AJ, Karjalainen A, Impivaara O, et al. Radiographic small lung opacities and pleural abnormalities as a consequence of asbestos exposure in an adult population. Scand J Work Environ Health 1995; 21: 470-477.

27. Hilt B, Hillerdal G, Lund-Larsen PG, Lien JT, Langård $\mathrm{S}$. Asbestos-related radiographic changes by ILO classification of $10 \times 10 \mathrm{~cm}$ chest X-rays in a screening of the general population. J Occup Environ Med 1995; 37 : 189-193.

28. Hillerdal G. Asbestos-related pleuropulmonary lesions and the erythrocyte sedimentation rate. Thorax 1984; 39: 752-758. 